\title{
The breeding pattern and variations in timing and reproductive output of the commercial sea cucumber Holothuria fuscogilva in Kenya
}

\author{
N. A. Muthiga ${ }^{1}$ and J. A. Kawaka ${ }^{1}$ \\ ${ }^{I}$ The Wildlife Conservation Society, Western Indian Ocean Project P.O. Box 99470, \\ Mombasa, Kenya, 80107.
}

Keywords: seasonality, Indian Ocean, Kenya, fecundity, sexual synchrony, Holothuria fuscogilva.

\begin{abstract}
The sea cucumber Holothuria fuscogilva is currently one of the most commercially valuable species of sea cucumber worldwide. This study investigated reproduction of this species in order to characterize the reproductive pattern and evaluate the relationship with temperature, light and lunar periodicity. Individuals were collected monthly, between 1998 and 2007, at Shimoni, Kenya and processed using standard gonad index methods and macroscopic and microscopic observations of the gonads. Gametogenesis commenced from May and spawning occurred from December to April of each year and there was close synchrony between the sexes, contrary to the hypothesis that breeding patterns on the equator will be continuous and less synchronized between sexes. Peak spawning occurred during the last quarter of the moon. The gonad index of individuals correlated significantly with gonad tubule length and fecundity indicating that it was a good predictor of sexual maturity and reproductive output. The gonad index showed a significant correlation with temperature but not light, suggesting that temperature may play a role in controlling reproduction. The life history strategy of this sea cucumber included a higher energetic investment in the reproductive output of females and spawning at a time favorable for larval development. There was a shift in sex ratio from unity to significantly more males over the sampling period, as well as a significant reduction in mean sizes (body wall weight) and reproductive output (gonad index) suggesting that the reproductive success of this species was potentially negatively affected by fishing.
\end{abstract}

\section{INTRODUCTION}

Holothurians (sea cucumbers) have been harvested for hundreds of years in many nations of the Western Indian Ocean and an increasing demand to supply the global market, has led to unsustainable fishing and over-exploitation of natural stocks (Marshall et al., 2001; Lovatelli et al., 2004; Conand \& Muthiga, 2007; Conand, 2008).
Several management measures including minimum size limits, gear restrictions, closed seasons and mariculture are either currently under consideration or implementation (Conand \& Muthiga, 2007). These management interventions rely in part on knowledge of the reproductive biology of sea cucumbers, however, there is relatively little information on the reproductive biology 
of many tropical commercial species of sea cucumbers (Bruckner, 2006; Conand \& Muthiga, 2007; Conand, 2008).

The sea cucumber Holothuria fuscogilva is currently one of the most commercially valuable species of sea cucumber worldwide (Bruckner, 2006). It is widely distributed and harvested throughout the WIO (Marshall et al., 2001; Conand \& Muthiga, 2007). In previous studies on this species, an annual pattern of reproduction was reported in New Caledonia (Conand, 1993), the Maldives (Reichenbach, 1999), and the Solomon Islands (Ramofafia et $a l ., 2000)$ and photoperiod and temperature were reported as the controlling factors.

The Kenyan coast occurs at the equator and is exposed to monsoonal seasonality with varying oceanographic conditions of temperature, light, and productivity (McClanahan, 1988). Studies along the Kenyan coast are therefore suitable for testing the effects of monsoonal seasonality on breeding patterns of marine invertebrates. Holothuria fuscogilva is an important component of the catch (Muthiga \& Ndirangu, 2000) and it was selected as part of a larger regional project to assess the reproduction of sea cucumber species of commercial value (Conand et al., 2006). The aims of the current study were to 1) describe the reproductive pattern of $H$. fuscogilva, 2) determine the relationship between reproduction and environmental factors (temperature, light and lunar period), and 3) test the hypothesis that reproduction will show a weak seasonal pattern at the equator due to reduced variability of the environmental factors that control gametogenesis and spawning.

\section{MATERIALS AND METHODS}

The study was undertaken at Shimoni (Lat $4^{\circ} \mathrm{S}$ ) in Kwale district, in the south coast of Kenya, between the sampling periods; December 1998 to December 1999, April 2000 to March 2001 and January 2006 to January 2007. Within each of these sampling periods, monthly samples of 10-20 Holothuria fuscogilva individuals were collected by fishermen using SCUBA at a depth of $18-25 \mathrm{~m}$. All individuals encountered during each dive were collected irrespective of their size, placed in polythene bags (to retain any eviscerated organs) filled with seawater mixed with $0.5 \mathrm{M} \mathrm{MgCl}$ and transported to the Shimoni fisheries office laboratory where dissections were carried out.

\section{Reproductive pattern}

Individual sea cucumbers were dissected and processed using standard methods detailed in Muthiga \& Conand (2006). Gonad indices were calculated using the formula: gonad wet weight/body wall wet weight $\mathrm{x} 100$. Sex and maturity stage were determined from the color and morphology of the gonad and observation of gonad tubules under a binocular microscope.

The Chi-squared test was used to test whether there was a significant difference in the number of males and females sampled (sex-ratio) in each sampling period. The relationship between individual body size and gonad growth was determined by a correlation of body wall wet weight $(\mathrm{g})$ and gonad index $(\%)$. The differences between the males and females was determined through a single factor ANOVA of gonad indices and the level of sexual synchrony between the sexes was determined by a correlation between the mean monthly gonad index of females and males.

The variability in reproduction between the months and between the years was determined by testing the gonad index data for normality using the Shapiro-Wilk W test; if found not to be normally distributed, the Kruskal-Wallis test was then used to test for differences in the gonad indices between months and between years.

\section{Reproductive output}

The reproductive output of $H$. fuscogilva was investigated from measurements of 1) the gonad size (gonad wet weight $(\mathrm{g})$ and gonad tubule length (mm)); and, 2) fecundity measured as the number of oocytes a female produced during the peak reproductive period (oocytes/female). Gonad tubule length and fecundity were only measured for the peak reproductive period (June - November) of the 


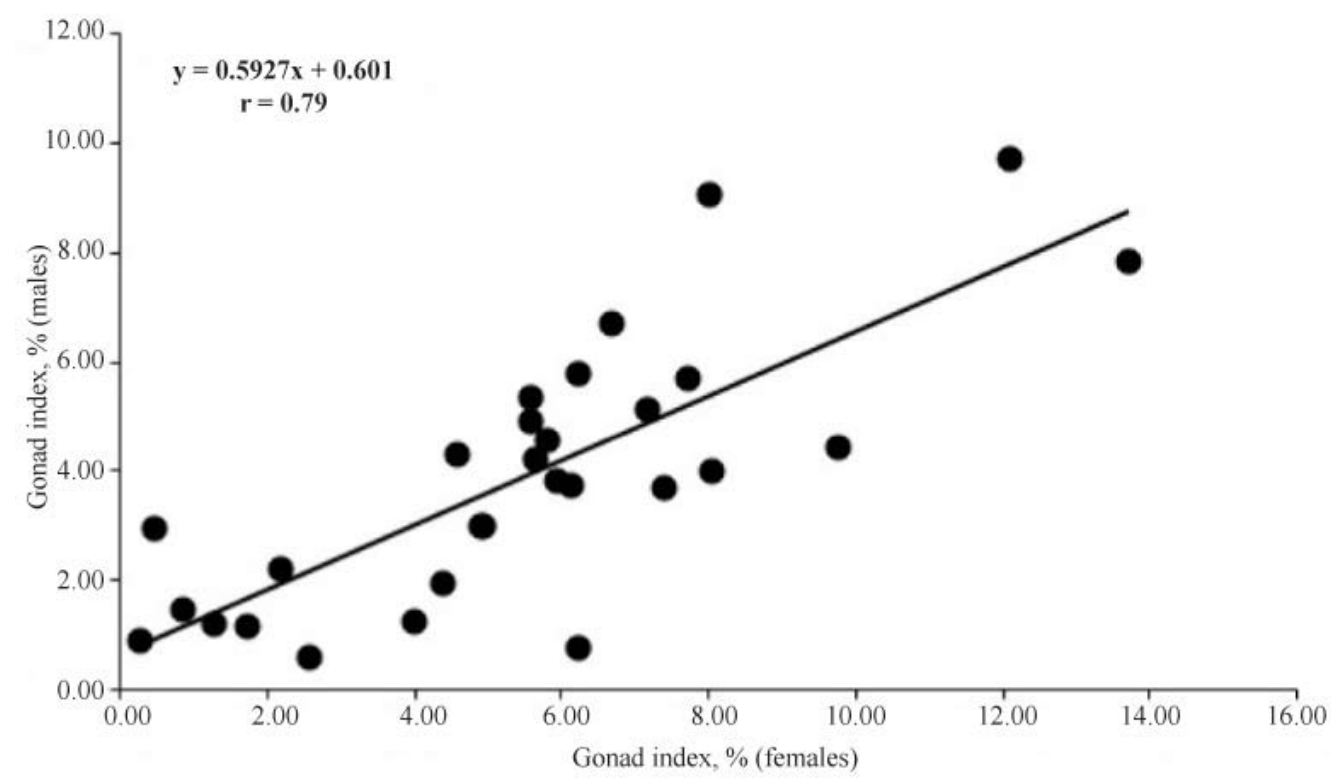

Fig. 1. The relationship between the mean monthly gonad indices of female and male Holothuria fuscogilva collected in Shimoni, Kenya between 1998 and 2007. Ten to twenty individuals were collected monthly

2006 - 2007 samples. The gonad tubule length was measured from the gonad basis to the tip of the longest gonad tubules, while fecundity was calculated as the number of oocytes in a given weight of preserved gonad tissue using methods detailed in Muthiga (1996). The fecundity was calculated as: Oocytes /female $=$ the average number of oocytes per aliquot $\mathrm{x}$ the dilution factor $\mathrm{x}$ the proportion of the weight of the piece of gonad to the total gonad weight. The relationship between individual and monthly averages of gonad tubules, gonad size and fecundity was determined through correlations of these parameters.

\section{Temperature, light and lunar period}

Air temperature $\left({ }^{\circ} \mathrm{C}\right)$ and light (Einstein $/ \mathrm{m}^{2} /$ day) were obtained from NOAA satellite data, averaged for each month for the respective years and correlated against the mean monthly gonad index. Lunar periodicity was tested by calculating the average gonad index for each lunar day (new moon = lunar day 0 ) and correlating this against the lunar day.

\section{RESULTS}

\section{Reproductive pattern}

The size of the individuals collected at Shimoni ranged from $115 \mathrm{~g}$ to $2390 \mathrm{~g}(\mathrm{n}=553)$ and there was no significant difference (Table 1) in the average body wall weights of males (1384 $\pm 19.8)$ and females $(1330 \pm 20.6)$. Nineteen individuals that could not be sexed had much lower body wall weights $(918 \pm 78)$. The sex ratio for samples collected in 1998 - 1999 (0.91: 1$)$ and $2001-2002(1.07: 1)$ did not differ significantly from unity $\left(\chi^{2}=0.41\right.$; df $=196$ and $\chi^{2}=0.17$; $\mathrm{df}=142$ respectively). There were however, significantly more males (113) than females (82) in the $2006-2007$ samples $\left(\chi^{2}=4.93 ; \mathrm{df}=194 ; \mathrm{p}=0.05\right)$.

The relationship between the body wall weight and gonad weight of individuals was significant (Table 2) but not between weight and gonad index (Table 2). There was also a statistically significant relationship between the monthly gonad index of the sexes (Fig. 1) hence gonad index data of females and males were pooled for all years for illustration of 
Table 1. The morphological characteristics of Holothuria fuscogilva collected in Shimoni on the south coast of Kenya. The mean $( \pm$ SEM) for females $(n=250)$ and for males $(n=285)$ and the overall means are provided. Single factor ANOVA is used for comparison between females and males

\begin{tabular}{lcccc}
\hline Characteristic & Females & Males & Overall & Comparison \\
\hline Body weight $(\mathrm{g})$ & $1330.42 \pm 20.64$ & $1383.53 \pm 19.80$ & $1343.59 \pm 14.48$ & $\mathrm{~F}=0.28 ; \mathrm{p}=0.59$ \\
Gonad weight $(\mathrm{g})$ & $95.41 \pm 5.14$ & $63.36 \pm 3.36$ & $75.70 \pm 2.98$ & $\mathrm{~F}=36.55 ; \mathrm{p}<0.001$ \\
Gonad index $(\%)$ & $6.19 \pm 0.33$ & $3.85 \pm 0.19$ & $4.77 \pm 0.19$ & $\mathrm{~F}=39 ; \mathrm{p}<0.001$ \\
\hline
\end{tabular}

the annual maturity cycle (Fig. 2). The annual reproductive maturity cycle showed a seasonal pattern that varied during the different years. For example, the gonad index of individuals in July and August of 2006-2007 samples were unusually high attributable to large individuals with large gonads. Gonad indices showed the lowest values in March to April (0.1-1.4\%) and increased markedly by June - July (6 $12 \%$ ). Gonad indices remained relatively high from July to November, then decreased markedly between December and February $(>4 \%)$. There was a weak but statistically significant variability in the gonad indices between the years $\left(\chi^{2}=7.46 ; \mathrm{p}=0.107\right.$; $\mathrm{df}=$
2) and a much stronger significant difference in the gonad indices between months $\left(\chi^{2}=\right.$ $175.1 ; \mathrm{p}=0.0001 ; \mathrm{df}=11$ ).

\section{Reproductive output}

Individuals had average gonad weights of $75.7 \pm 2.98 \mathrm{~g}$ and gonad indices of 4.77 $\pm 0.19 \%$. Females had on average $33 \%$ and $37 \%$ higher gonad weights and gonad indices than males (Table 1). There was also a significant correlation between the gonad weight and body wall weight of individual females $(r=0.18 ; p=0.003 ; n=250)$ and of males $(\mathrm{r}=0.32 ; \mathrm{p}=0.001 ; \mathrm{n}=287)$.

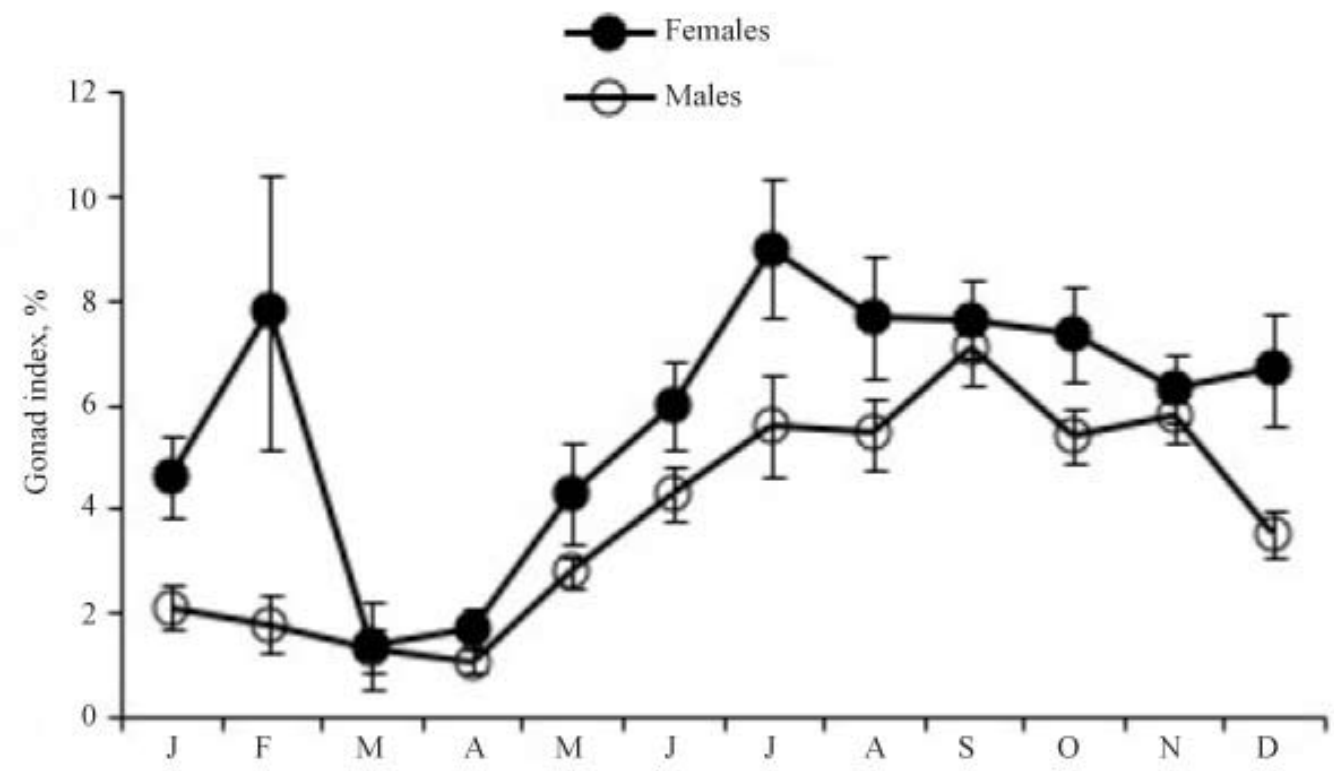

Fig. 2. The seasonal variation in the mean monthly gonad index $(\% \pm$ sem) of female (closed circle) and male (open circle) Holothuria fuscogilva collected in Shimoni, Kenya between 1998 and 2007. Ten to twenty individuals were collected monthly 
Table 2. Relationships between different morphological characteristics of Holothuria fuscogilva collected in Shimoni, Kenya and with environmental parameters (temperature and light). Units for gonad tubule length $=\mathrm{mm}$, fecundity $=x 10^{6}$ oocytes $/$ female, temperature $={ }^{\circ} \mathrm{C}$, and light $=$ Einstein $/ \mathrm{m}^{2} / \mathrm{day}$

\begin{tabular}{ll}
\hline Comparison & $\mathbf{r} / \mathbf{p}$ value \\
\hline Individual body weight vs. & $r=0.35 ; \mathrm{p}=0.05$ \\
$-\quad$ Gonad weight $(\mathrm{g})$ & $\mathrm{r}=0.04 ; \mathrm{ns}$ \\
$-\quad$ Gonad index $\%$ & $\mathrm{r}=0.47 ; \mathrm{p}=0.01$ \\
Gonad index vs. gonad tubule length (individuals) & $\mathrm{r}=0.51 ; \mathrm{ns}$ \\
Monthly gonad index vs. monthly gonad tubule length & $\mathrm{r}=0.54 ; \mathrm{p}=0.005$ \\
Gonad index vs. fecundity (individuals) & $\mathrm{r}=0.92 ; \mathrm{p}=0.0001$ \\
Monthly gonad index vs. monthly fecundity & $\mathrm{r}=0.32 ; \mathrm{p}=0.05$ \\
Gonad tubule length vs. fecundity (individuals) & $\mathrm{r}=0.49 ; \mathrm{ns}$ \\
Monthly gonad tubule length vs. monthly fecundity & $\mathrm{r}=0.20 ; \mathrm{ns}$ \\
Monthly gonad index vs. & $\mathrm{r}=0.87 ; \mathrm{p}=0.005$ \\
$-\quad$ Monthly light & $\mathrm{r}=0.41 ; \mathrm{p}=0.01$ \\
\hline
\end{tabular}

The gonad tubule lengths for individuals ranged from $5 \mathrm{~mm}$ to $196 \mathrm{~mm}$ and averaged $119.31 \pm 9.97 \mathrm{~mm}(\mathrm{n}=39)$. The gonad tubule lengths fluctuated throughout the year but the monthly averages followed a pattern similar to the monthly changes in gonad index and were significantly correlated with the gonad index (Table 2).

Fecundity varied between 0.07 to $24.51 \mathrm{x}$ $10^{6}$ oocytes/female with an average of $6.45 \pm$ $0.88 \times 10^{6}$ oocytes/female and was significantly correlated with the gonad index of individual females and when averaged monthly (Table 2). Although there was a significant relationship between the fecundity and gonad tubule length of individuals, the relationship between the mean monthly fecundity and mean monthly gonad tubule length was not significant (Table 2).

\section{Temperature, light and lunar period}

The monthly air temperatures showed a seasonal pattern with a peak in $\operatorname{March}\left(29.1^{\circ} \mathrm{C}\right)$ decreasing to $25.0^{\circ} \mathrm{C}$ in July-August. Light showed a similar pattern, peaking earlier in February (53.4
Einstein $/ \mathrm{m}^{2} /$ day) and decreasing to the lowest levels (38.4 Einstein $/ \mathrm{m}^{2} /$ day) by June. There was a significant and negative relationship between the average monthly temperature and gonad index averaged over the sampling period, but not between mean monthly light and mean monthly gonad index (Table 2). The average gonad index of individuals collected on different lunar days when reproductive activity was at its highest (July - December) was variable averaging from $<2 \%$ to $12 \%$ and showed a significantly negative relationship with the lunar day (Table 2).

\section{DISCUSSION}

\section{Reproductive pattern}

While seasonal reproductive patterns are typically reported for marine invertebrate species that occur in environments where seasonality is pronounced (Giese \& Pearse, 1974; Smiley et al., 1991), little information is available on reproduction in tropical environments that also experience seasonality but with less variation in temperature and other environmental parameters. Holothuria fuscogilva in this study showed a seasonal 
pattern with spawning occurring between December and April towards the end of the northeast monsoon period on the Kenyan coast. The general pattern of gonad growth and spawning was repeated in the three years and although there was variability between years in the timing of the onset of gametogenesis and spawning, the differences between the months within each year was much more significant than the inter-annual differences.

The pattern of reproduction does not support the hypothesis that marine organisms at the equator will breed year round (Orton, 1920; Giese \& Pearse, 1974; Smiley et al., 1991). This hypothesis has also been previously challenged in studies of sea urchins and sea cucumbers that have shown annual patterns of reproduction close to the equator (Pearse, 1968; Reichenbach, 1999; Muthiga \& Jaccarini, 2005; Muthiga, 2006). It has also been argued that reproductive synchrony within and between species will break down closer to the equator due to reduced variability in environmental parameters (Oliver et al., 1988). Gonad growth of the sexes however, was highly correlated, indicating tight synchrony between males and females. Sexual synchrony has previously been reported in $H$. fuscogilva (Conand, 1993; Ramofafia et al., 2000) and other sea cucumbers including $H$. scabra (Ramofafia et al., 2003), H. arenacava (Muthiga, 2006) and H. leucospilota (Drumm \& Loneragan, 2005; Gaudron et al., 2008).

The gonad index of individuals did not show a correlation with body size, indicating that the gonad index method is a reliable method for tracking reproductive maturity in H. fuscogilva (Grant \& Tyler, 1983). The gonad index increased gradually from April - May indicating the onset of gametogenesis and peaked in July - September and spawning commenced in November through to February. An annual pattern of reproduction (Table 3) has also been reported at sites closer to the equator in the Maldives $\left(7^{\circ} \mathrm{N}\right.$; Reichenbach, 1999), the Solomon Is. ( $9^{\circ} \mathrm{S}$; Ramofafia et al., 2000), and, at higher latitudes in New Caledonia $\left(20^{\circ} \mathrm{S}\right.$; Conand, 1993). Within this wide geographical range (+/- 16 degrees of latitude), $H$. fuscogilva has an annual pattern of reproduction only differing in timing of the onset of gametogenesis and the length of the spawning period, which suggests that this may be the common lifehistory strategy for this species.

\section{Reproductive output}

The reproductive output of marine invertebrates has been shown to be dependent on several factors, including sex, the individual size and ecological factors such as population density (Levitan, 1991; Muthiga, 2006).

There was a significant relationship between the gonad weight and body wall weight of individual $H$. fuscogilva in the present study which supports findings from other studies of sea cucumbers (Conand, 1993; Muthiga, 2006). The average gonad weight and gonad indices were almost twice as high in females than in males despite females having similar body weights on average as males which is comparable to studies of $H$. fuscogilva (Conand, 1993; Ramofafia et al., 2000) and other sea cucumber species (Conand, 1993; Ramofafia et al., 2003; Drumm \& Loneragan, 2005; Muthiga, 2006).

The average gonad indices reported for $H$. fuscogilva (mean 3.35\% for males and 6.19\% for females; maximum $\sim 28 \%$ ) were higher than individuals in the Solomon Is. (Ramofafia et al., 2000) that had gonad indices ranging from 3.69 $-4.59 \%$ and in New Caledonia that averaged $0.8-2.2 \%$. Variability in reproductive output in different populations of marine invertebrates has been reported in several studies that show food availability as the driving factor controlling body size and reproductive output (Levitan, 1989; Muthiga \& Jaccarini, 2005).

The male to female ratio was at unity in 1998 - 1999 and 2000 - 2001 samples but a shift to significantly more males occurred in the $2006-2007$ samples. A shift in sex ratio towards males has been reported in $H$. scabra populations under heavy fishing pressure in the Red Sea (Hassan, 2005) and in H. whitmaei in the Great Barrier Reef, Australia (Shiell \& 
Table 3. Summary of the reproductive periods of Holothuria fuscogilva across its distribution

\begin{tabular}{llll}
\hline Location & Latitude & Reproductive period & Reference \\
\hline Maldives & $7^{\circ} \mathrm{N}$ & Annual, spawning from December to March & Reichenbach, 1999 \\
Shimoni, Kenya & $4^{\circ} \mathrm{S}$ & $\begin{array}{l}\text { Annual, gametogenesis starts from May, } \\
\text { spawning from December to April }\end{array}$ & Present study \\
Solomon Islands & $9^{\circ} \mathrm{S}$ & $\begin{array}{l}\text { Annual, gametogenesis initiated in March, } \\
\text { spawning from August - October }\end{array}$ & Ramofafia et al., 2000 \\
New Caledonia & $21^{\circ} \mathrm{S}$ & Annual, spawning from November to January & Conand, 1993 \\
\hline
\end{tabular}

Uthicke, 2006). Since reproductive success is partly dependent on the abundance and distribution of adults, and the availability of gametes of both sexes (Levitan, 1991; 2005), the shift to more males could significantly reduce the overall reproductive success of the southern Kenyan population of $H$. fuscogilva.

Large gonads in individuals are often interpreted as an indicator of a high reproductive output because larger gonads usually produce more gametes. There was a strong relationship between the number of gametes (measured as fecundity) and the size of the gonad (measured as gonad index and gonad tubule length) indicating that gonad size is a reliable predictor of individual reproductive output for H. fuscogilva. Gonad tubule length has also been shown to correlate with sexual maturity in H. fuscogilva in the Solomon Is. (Ramofafia et al., 2002) and with gonad index in $H$. whitmaei (Shiell \& Uthicke, 2006). Mature tubules ranged in size between 77 and $107 \mathrm{~mm}$ long, which is comparable to $H$. fuscogilva in the Solomon Is. (50 - $180 \mathrm{~mm}$; Ramofafia et al., 2000).

Individual $H$. fuscogilva produced up to 24 million oocytes per female with an average of 11 million oocytes per female at the peak reproductive period. This compares favorably with estimates by Conand (1993) of 6-14 million oocytes per female. In addition, there was a significant correlation between fecundity and female size indicating that larger females produced more eggs, which has been shown in several species of echinoderms including starfish, sea urchins and sea cucumbers (Chia, 1966; Conand, 1993; Muthiga, 1996; Toral-
Granda \& Martinez, 2007). Monthly changes in fecundity correlated significantly with monthly changes in gonad index indicating that the pattern of gonad growth is a good predictor of the reproductive maturity cycle and can be used to estimate the peak time of egg availability in H. fuscogilva on the Kenyan coast, a parameter that is useful for mariculture. Since the highest gonad indices coincided with the highest fecundity and the longest gonad tubules, tubule length may be used as a proxy when minimum invasive procedures such as those developed by Reichenbach (1999) are required in studies of reproduction in sea cucumbers.

\section{Temperature, light and lunar period}

Temperature and light have been suggested to control gametogenesis and spawning in sea cucumbers (Smiley et al., 1991; Conand, 1981; 1993; Ramofafia et al., 2000; Muthiga, 2006). Both these environmental factors exhibit a seasonal pattern along the Kenyan coast (McClanahan, 1988). The gonad index of $H$. fuscogilva showed a highly significant correlation with temperature but not with light which suggests that temperature may play a role in reproduction in this species. Previous studies on the reproduction of $H$. arenacava (Muthiga, 2006) and H. scabra (Muthiga et al., 2009) on the Kenyan coast, showed a significant correlation between the gonad index and both temperature and light. One explanation for a lack of correlation between gonad growth and light in H. fuscogilva tested in the present study 
could be the differences in the light regime where this species occurs. Both $H$. arenacava and $H$. scabra were found in relatively shallow waters (up to $8 \mathrm{~m}$ ) while $H$. fuscogilva was collected between $18-25 \mathrm{~m}$. Although light was not measured directly at the study site in this study, light is possibly lower and less variable at depth than in shallow waters and will therefore not be expected to have a strong influence on the reproduction in $H$. fuscogilva.

Another aspect of light, the photoperiod (or day length), has been shown to control reproduction in starfish and sea urchins (Pearse \& Eernisse, 1982; Pearse et al., 1986), to influence gonad development in the sea cucumbers $H$. fuscogilva in the Solomon Islands (Ramofafia et al., 2000), Actinopyga mauritiana in Guam (Hopper et al., 1998), as well as H. nobilis, Thelonata ananas, Stichopus variegatus in New Caledonia (Conand, 1981; 1993) and H. scabra in the Solomon Islands (Ramofafia et al., 2003). All these locations have larger variability in day length than more equatorial locations such as the Kenyan coast where day length varies by $<$ 30 minutes per year. It is likely that the small change in day length on the Kenyan coast is not a sufficiently strong cue, especially in a species that occurs in deeper waters.

Moonlight has also been shown to control spawning in many species of sea cucumbers with several studies reporting spawning at the full moon (Babcock et al., 1992; Mercier et al., 2000; 2007). There was a correlation between gonad index and lunar day (during the peak reproductive period) in this study, with the highest gonad indices occurring during the first quarter and the lowest during the last quarter of the moon. No field observations of $H$. fuscogilva have been reported that verify lunar periodicity.

In addition to studies on echinoderms reporting annual patterns of reproduction on the Kenyan coast (Muthiga \& Jaccarini, 2005; Muthiga, 2005; 2006), there is growing evidence that other marine species including finfish, barnacles and oysters (Nzioka, 1979; Ntiba \& Jaccarini, 1990; Ruwa \& Polk, 1994) also exhibit annual patterns of reproduction and settlement. This implies that the environmental seasonality of the Kenyan coast probably acts as the proximate driver of the timing of gametogenesis and spawning in marine species.

\section{CONCLUSION}

The results of this study indicate that H. fuscogilva has an annual pattern of reproduction on the Kenyan coast, that is similar to other studies across its range of distribution, suggesting that this is the common mode of reproduction in this species. This fact and the presence of reproductive synchrony between the sexes is counter to the hypothesis that reproduction will show a weak seasonal pattern at the equator due to reduced variability of the environmental factors that control gametogenesis and spawning. Although temperature showed a significant correlation with gonad index, further experiments would have to be carried out to establish if and how temperature affects reproduction. The shift in sex ratio from unity towards significantly more males suggested a negative impact of fishing pressure, however, further studies on the effects of fishing on the population structure, growth and recruitment of this species are needed to support this finding. This is the first study of $H$. fuscogilva in East Africa and increases our knowledge of this highly valuable and widely distributed commercial sea cucumber. The study provides information including morphometric data, information on sexual maturity, reproductive seasonality, reproductive output including fecundity and gonad tubule length that are useful for mariculture and management as well as potential biological signs that reflect the impacts of overfishing.

Acknowledgements -We are grateful to the Fisheries Department, Kenya Marine and Fisheries Research Institute, the Kenya Wildlife Service and the Wildlife Conservation Society who provided the laboratory and library facilities, boats and vehicles and other in-kind support for our work. We thank the Western Indian Ocean Marine Science Association under the Marine Science for Management (MASMA) 
program for funding the study. This research was carried out under Research Permit No. MOST 13/001/38C67 from the Kenyan Ministry of Science and Technology and complies with the research requirements of Kenya.

\section{REFERENCES}

Babcock, R.C., Mundy, C., Kessing, J.K. \& Oliver, J. (1992) Predictable and unpredictable spawning events: in situ behavioral data from free-spawning coral reef invertebrates. Invertebr. Reprod. Dev. 22: 213-228.

Bruckner, A. (2006) The proceedings of the technical workshop on the conservation of sea cucumbers in the families Holothuridae and Stichopodidae. NOAA Technical Memorandum NMFSOPR 44, Silver Spring, Maryland

Chia, F.S. (1966) Systematics of the six-rayed sea star, Leptasteria, in the vicinity of San Juan Island, Washington. Syst. Zool. 15: 300-306.

Conand, C. (1981) Sexual reproduction of three commercially important holothurian species (Echinodermata) from the lagoon of New Caledonia. Bull. Mar. Sci. 31: 523-543.

Conand, C. (1993) Reproductive biology of the holothurians from the major communities of the new Caledonian lagoon. Mar. Biol. 116: 439-450.

Conand, C. (2008) Population status, fisheries and trade of sea cucumbers in Africa and Indian ocean 153-205. In: Toral-Granda, V., Lovatelli, A., Vasconcellos, M. (eds) Sea cucumbers. A global review on fishery and trade. FAO Fisheries Technical Paper. No. 516. Rome, FAO. Pp. 153 - 205.

Conand, C. \& Muthiga, N.A. (2007) (eds). Commercial sea cucumbers: A review for the Western Indian Ocean. WIOMSA Book Series No. 5.

Conand, C., Muthiga, N., Aumeerudy, R., de La Torre-Castro, M., Frouin, P., Mgaya, Y., Mirault, E., Ochiewo, J. \& Rasolofonirina, R. (2006) A three-year project on sea cucumbers in the southwestern Indian Ocean: National and regional analyses to improve management. SPC. Beche-de-Mer. Info. Bull. 23: 11-15.

Drumm, D.J.\&Loneragan, N.R.(2005) Reproductive biology of Holothuria leucospilota in the Cook Islands and the implications of traditional fishing of gonads on the population. NZ. J. Mar. Freshw. Res. 39: 141-156.
Gaudron S., Kohler S. \& Conand C. (2008). Reproduction of the sea cucumber Holothuria leucospilota in the fringing reef of Reunion Island (Western Indian Ocean): biological and ecological aspects. Invertebr. Reprod. Dev. 51 (1): 19-31.

Giese, A.C. \& Pearse, J.S. (1974) Introduction: general principles. In: Giese, A.C., Pearse J, (eds) Reproduction of Marine Invertebrates, Vol I. Academic Press, New York. pp 1-49.

Grant, A. \& Tyler, P.A. (1983) The analysis of data in studies of invertebrate reproduction. 1. Introduction and statistical analysis of gonad indices and maturity indices. Int. J. Invert. Reprod. 6: 259-269.

Hasan, M.H., 2005. Destruction of a Holothuria scabra population by overfishing at Abu Rhamada Island in the Red Sea. Mar. Envi. Res. 60: 489-511.

Hopper, D.R., Hunter, C.L. \& Richmond, R.H. (1998) Sexual reproduction of the tropical sea cucumber, Actinopyga mauritiana (Echinodermata: Holothuroidea) in Guam. Bull. Mar. Sci. 61: 1-9.

Levitan, D.R. (1989) Density-dependent size regulation in Diadema antillarum: effects on fecundity and survivorship. Ecology 70: 1414-1424.

Levitan, D.R. (1991) Influence of body size and population density on fertilization success and reproductive output in a free-spawning invertebrate. Biol. Bull. 181: 261-268.

Levitan, D.R. (2005) The distribution of male and female reproductive success in a broadcast spawning marine invertebrate. Integr. Comp. Biol. 45: 848-855.

Lovatelli, A.C., Conand. C., Purcell, S., Uthicke, S., Hamel, J. \& Mercier, A. (2004) Advances in sea cucumber aquaculture and management. FAO, Rome.

Marshall, N.T., Milledge, A.H. \& Afonso, P.S. (2001) Trade review: Stormy seas for marine invertebrates: trade in sea cucumbers, seashells and lobsters in Kenya, Tanzania and Mozambique. WWF, IUCN.

McClanahan, T.R. (1988) Seasonality in East Africa's coastal waters. Mar. Ecol. Prog. Ser. 44: 191-199.

Mercier, A., Battaglene, S.C. \& Hamel, J. (2000) Periodic movement, recruitment and sizerelated distribution of the sea cucumber Holothuria scabra in Solomon Islands. Hydrobiologia 440: 81-100. 
Mercier, A., Ycaza, R.H. \& Hamel, J.F. (2007) Longterm study of gamete release in a broadcastspawning holothurian: predictable lunar and diel periodicities. Mar. Ecol. Prog. Ser. 329: 179-189.

Muthiga, N. (1996). The role of early life history strategies on the population dynamics of the sea urchin Echinometra mathaei (de Blainville) on reefs in Kenya. $\mathrm{PhD}$ dissertation, Zoology Department, University of Nairobi Kenya.

Muthiga, N. (2006) The reproduction of a new species of sea cucumber, Holothuria (Mertensiothuria) arenacava in a Kenyan marine protected area: the possible role of light and temperature on gametogenesis and spawning. Mar. Biol. 149: 585-593.

Muthiga, N. \& Ndirangu, S. (2000) Village based larviculture and stock enhancement of sea cucumbers (Echinodermata: Holothuroidea) on the Kenyan coast. Final Technical Report, Biodiversity Support Fund.

Muthiga, N. \& Jaccarini, V. (2005) Effects of seasonality and population density on the reproduction of the Indo-Pacific echinoid Echinometra mathaei in Kenyan coral reef lagoons. Mar. Biol. 146: 445-453.

Muthiga, N. \& Conand, C. (2006) Regional sea cucumber project: Proceedings of the start-up workshop, Mombasa Kenya, 26-29 January 2006. 20pp.

Muthiga NA, Kawaka JA, Ndirangu S. (2009) The timing and reproductive output of the commercial sea cucumber Holothuria scabra on the Kenyan coast. Estuar., Coast. Shelf Sci., 84: 353-360.

Ntiba, M.J. \& Jaccarini, V. (1990) Gonad maturation and spawning times of Siganus sutor off the Kenyan coast: evidence for definite spawning seasons in a tropical fish. J. Fish. Biol. 14: 315-325.

Nzioka, R.M. (1979) Observations on the spawning seasons of East African reef fishes. J. Fish. Biol. 14: 329-342.

Oliver, J.K., Babcock, R.C., Harrison, P.L. \& Willis, B.L. (1988) Geographic extent of mass coral spawning: clues to ultimate causal factors. Proc 6th Int. Coral. Reef. Symp. 2: 803-810.

Orton, J.H. (1920) Sea temperature, breeding and distribution of marine animals. J. Mar. Biol. Assoc. UK. 12: 339-366.
Pearse, J.S. (1968) Patterns of reproductive periodicities in four species of Indo-Pacific echinoderms. Proc. Indian. Acad. Sci. 67: 247-279.

Pearse, J.S. \& Eernisse, D.J. (1982) Photoperiodic regulation of gametogenesis and gonadal growth in the sea star Pisaster ochraceus. Mar. Biol. 67: 121-125.

Pearse, J.S., Pearse, V.B. \& Davis, K.K. (1986) Photoperiodic regulation of gametogenesis and growth in the sea urchin Strongylocentrotus purpuratus. J. Exp. Zool. 237: 107-118.

Ramofafia, C., Battaglene, S.C., Bell, J.D. \& Byrne, M. (2000) Reproductive biology of the commercial sea cucumber Holothuria fuscogilva in the Solomon Islands. Mar. Biol. 136: $1045-1056$.

Ramofafia, C., Byrne, M. \& Battaglene, S.C. (2003) Reproduction of the commercial sea cucumber Holothuria scabra (Echinodermata: Holothuroidea) in the Solomon Islands. Mar. Biol. 142: 281-288.

Reichenbach, N. (1999) Ecology and fishery biology of Holothuria fuscogilva (Echinodermata: Holothuroidea) in the Maldives, Indian Ocean. Bull. Mar. Sci. 64: 103 - 113.

Ruwa, R.K. \& Polk, P. (1994) Patterns of spat settlement recorded for the tropical oyster Crassostrea cucullata (Born 1778) and the barnacle, Balanus amphitrite (Darwin 1854) in a mangrove creek. Trop. Zool. 7: 121-130.

Shiell, G.R., Uthicke, S., 2006. Reproduction of the commercial sea cucumber Holothuria whitmaei [Holothuroidea:Aspidochirotda] in the Indian and Pacific Ocean regions of Australia. Mar. Biol. 148: 973-986.

Smiley, S., McEuen, F-S., Chaffee, C. \& Krishan, S. (1991) Echinodermata: Holothuroidea. In: Giese, A.C., Pearse, J.S. \& Pearse, V.B. (eds) Reproduction of marine invertebrates. Vol. VI: Echinoderms and Lophophorates. Boxwood Press, Pacific Grove, California. Pp. 663-750.

Toral-Granda, V. \& Martinez, P. (2007) Reproductive biology and population structure of the sea cucumber Isostichopus fuscus (Ludwig, 1875) (Holothuroidea) in Caamaño, Galápagos Islands Ecuador. Mar. Biol. 151: 2091-2098. 